\title{
BARIUM AND LEAD LEVELS IN SITES FOR DISPOSAL OF OIL WELL WASTE ${ }^{1}$
}

\author{
NELSON MOURA BRASIL DO AMARAL SOBRINHO ${ }^{2}$, MARCOS BACIS CEDDIA², EVERALDO ZONTA ${ }^{2}$, \\ CAMILA DA COSTA BARROS DE SOUZA ${ }^{2 *}$, ERICA SOUTO ABREU LIMA ${ }^{2}$
}

\begin{abstract}
Indiscriminate disposal of waste from the oil industry has led to contamination of soils and water sources and toxic effects in the biota. Thus, this study aimed to assess barium $(\mathrm{Ba})$ and lead $(\mathrm{Pb}) \mathrm{spatial}$ variability in disposal sites for oil well drilling and prospecting wastes. The soil in the study area is classified as Red Latosol, and the area is located in Santa Maria do Oeste, Paraná State (Brazil). Barium and Pb spatial variabilities were determined using a 76-point sampling grid. The levels of metals were determined in soil samples collected at each sampling point, at the depth ranges of 0.0-0.3, 0.3-0.6, 0.6-0.9 and 0.9-1.2 m. Data were mapped using geostatistical interpolators for spatial dependence determination, modeling and validation of semivariograms, and respective interpolation. Thirty $\mathrm{Ba}$ and $\mathrm{Pb}$ high concentration samples were selected for leaching and solubilization assays. As semivariogram analysis showed spatial dependence, mapping by ordinary kriging was performed for both metals. The high levels found for both metals arose from well drilling activities, as no direct relationship was found between such levels with geology and genesis of the local rock. The concentrations of the metals were higher than the research values considering the Agricultural / AP-Max scenario, therefore, the study area was characterized as class 4 (contaminated). Although these metals have low solubility, i.e. low contamination risk to subsurface waters, they may pose contamination risks to water bodies by means of soil runoff.
\end{abstract}

Keywords: Geostatistics. Heavy metal. Soil contamination.

\section{BÁRIO E CHUMBO EM ÁREAS DE DISPOSIÇÃo DE RESÍDUOS DE POÇOS DE PETRÓLEO}

RESUMO - A disposição indiscriminada de resíduos da indústria petrolífera levam a contaminação dos solos e mananciais, afetando toda a biota. O objetivo do trabalho foi avaliar a variabilidade espacial dos teores de bário e chumbo em área de disposição de resíduos de perfuração de poços de petróleo. O Latossolo estudado encontra-se no município de Santa Maria do Oeste, no estado do Paraná-Brasil. Para a determinação da variabilidade espacial dos metais criou-se uma grade de amostragem com 76 pontos. Em cada ponto, foram coletadas amostras de solo nas profundidades: 0-0.3, 0.3-0.6, 0.6-0.9 e 0.9-1.2 m para a determinação dos teores de bário e chumbo. A geração dos mapas de bário e chumbo foi realizada através de interpoladores geoestatísticos com determinação da dependência espacial, modelagem e validação de semivariogramas experimentais e sua interpolação. Selecionou-se 30 amostras com concentrações de bário e chumbo mais elevadas para realização de ensaios de lixiviação e solubilização. Na análise do semivariograma verificou-se dependência espacial, permitindo a confecção de mapas por krigagem para os dois metais. Os elevados teores encontrados foram decorrentes das atividades associadas à perfuração de poços, visto que, não foi encontrado correspondência direta com a geologia das rochas locais e a gênese. As concentrações dos metais foram superiores aos valores de investigação considerando o cenário Agrícola/AP-Máx, caracterizando a área sujeita a "Investigação", pertencendo a Classe 4, área contaminada. Apesar desses metais possuírem baixa solubilidade, demonstrando baixo risco de contaminação de águas subsuperficiais, podem apresentar risco de contaminação de corpos d'água por meio do carreamento desse solo.

Palavras-chave: Geoestatística. Metal pesado. Contaminação de solo.

\footnotetext{
${ }^{*}$ Corresponding author

${ }^{1}$ Received for publication in 12/12/2018; accepted in 08/28/2019.

${ }^{2}$ Soil Departament, Universidade Federal Rural do Rio de Janeiro, Seropédica, RJ, Brazil; nmbdas@gmail.com - ORCID: 0000-0002-5053 -7338, marcosceddia@gmail.com - ORCID: 0000-0002-8611-314X, zontae@gmail.com - ORCID: 0000-0001-8106-0504, camilacostabarros@gmail.com - ORCID: 0000-0002-5253-3197, ericaabreulima@gmail.com-ORCID: 0000-0003-4140-3634.
}

Rev. Caatinga, Mossoró, v. 32, n. 4, p. 1060 - 1068, out. - dez., 2019 


\section{INTRODUCTION}

Oil industry produces a large range of wastes that, when indiscriminately disposed, can contaminate soils and groundwater and impact biota (BUSINELLI et al., 2009). One of the wastes produced by onshore well drilling operations is gravel, which is disposed in high amounts and has potentially toxic substances. This basically consists of a mixture of fragmented rocks and drilling fluids (BAUDER et al., 2005).

In general, drilling fluids contain hydrocarbons, sodium, and heavy metals such as barium $(\mathrm{Ba})$ and lead $(\mathrm{Pb})$ (BAKKE; KLUNGSØYR; SANNI, 2013; ANDRADE et al., 2014; FREITAS et al., 2015). Among the main components, barite $\left(\mathrm{BaSO}_{4}\right)$ adds large amounts of $\mathrm{Ba}$ to the waste produced (LIMA et al., 2012; MAGALHÃES et al., 2014a). Moreover, oil- and water-based fluids may contain diesel oil in their compositions (SANTOS, 2012), adding metals such as $\mathrm{Pb}$ to the oil well drilling waste.

Recent studies have shown phytotoxicity risks and groundwater contamination caused by $\mathrm{Ba}$ from barite are very low, except under extreme reduction conditions $(\mathrm{Eh}<-250 \mathrm{mV})$. Under this condition, increased solubility and consequently increased mobility and bioavailability of $\mathrm{Ba}$ have been observed (LIMA et al., 2012; MAGALHÃES et al., 2014a; MAGALHÃES et al., 2014b; SAMPAIO JUNIOR et al., 2015). Although the risks of groundwater contamination by $\mathrm{Pb}$ are also low, continued disposal of oil well drilling residues into the soil for prolonged periods of time can result in contamination thereof. Andrade et al. (2014) verified that after 20 years of waste disposal into a typical dystrophic Red Latosol, it presented $350.4 \mathrm{mg} \mathrm{kg}^{-1}$ $\mathrm{Pb}$ in its composition.

Among the numerous soil-polluting contaminants, heavy metals are especially dangerous due to high toxicity, environmental persistence, and food-chain bioaccumulation (ESMAEILI et al., 2014). Even in small amounts, contamination by heavy metals can cause environmental and public health problems (ONG et al., 2013; ESMAEILI et al., 2014; GHERASIM; MIKULASEK, 2014).

Studies on concentrations and spatial distribution of heavy metals in the soil are extremely important to identify the location and extent of the polluted area. In this sense, geostatistics has been used as a tool in studies of spatial variability of heavy metals in contaminated soils (CARVALHO; SILVEIRA; VIEIRA, 2002). Through this technique, the most relevant areas, in terms of contamination and remediation needs, can be identified, enabling more targeted actions and minimizing costs (AMARAL SOBRINHO et al., 2018).

Based on the above, this study aimed to evaluate $\mathrm{Ba}$ and $\mathrm{Pb}$ solubility in disposal sites for oil well drilling and prospecting wastes and to determine the spatial variability of their pseudo-total contents in contaminated soils. In brief, the purpose was to characterize $\mathrm{Ba}$ and $\mathrm{Pb}$ spatial variability and analyze the behavior of such metals in the environment.

\section{MATERIAL E MÉTODOS}

\section{Study area and sampling}

The study was carried out in a disposal site for oil well drilling and prospecting wastes. The area is located in Santa Maria do Oeste, Paraná State Brazil (24 56' 20" S, 51 51' 46" W). The local soil was previously characterized according to Donagemma et al. (2011) and classified by Santos et al. (2013) as typical dystrophic Red Latosol, moderate A, and wavy relief. Table 1 describes the soil physical and chemical features.

Table 1. Soil chemical and particle-size characterizations (Red Latosol).

\begin{tabular}{|c|c|c|c|c|c|c|c|c|c|c|c|c|c|c|c|}
\hline Symbol & $\begin{array}{l}\text { Jers } \\
\text { Depth } \\
\text { m }\end{array}$ & $\begin{array}{c}\mathrm{pH} \\
\left(\mathrm{H}_{2} \mathrm{O}\right)\end{array}$ & $\mathrm{Ca}^{2+}$ & $\mathrm{Mg}^{2+}$ & $\begin{array}{l}\mathrm{H}+\mathrm{Al} \\
\mathrm{m}^{1-}-----\cdot\end{array}$ & $\mathrm{Al}^{3+}$ & $\mathrm{S}$ & $\mathrm{T}$ & $\mathrm{V}$ & \multicolumn{2}{|c|}{$\begin{array}{l}\text { P } \mathrm{K} \\
\mathrm{mg} \mathrm{kg}^{-1}\end{array}$} & $\mathrm{C}$ & Sand & Silt & Clay \\
\hline $\mathrm{Ap}$ & $0-0.1$ & 5.2 & 4.9 & 0.6 & 7.6 & 0.0 & 5.8 & 13.4 & 43 & 1 & 10.6 & 25.4 & 141 & 302 & $\overline{557}$ \\
\hline BA & $0.1-0.2$ & 5.2 & 3.6 & 0.6 & 8.9 & 0.9 & 4.4 & 13.3 & 33 & 1 & 5.5 & 19.2 & 107 & 280 & 613 \\
\hline $\mathrm{Bw}_{1}$ & $0.2-0.3$ & 5.0 & 1.6 & 1.3 & 8.9 & 1.6 & 3.0 & 11.9 & 25 & 1 & 2.7 & 11.4 & 136 & 198 & 666 \\
\hline $\mathrm{Bw}_{2}$ & $0.3-0.6$ & 5.0 & 2.1 & 0.2 & 8.9 & 1.9 & 2.4 & 11.3 & 21 & 1 & 1.2 & 8.9 & 79 & 151 & 770 \\
\hline $\mathrm{Bw}_{3}$ & $0.6-1.0$ & 5.1 & 1.5 & 0.8 & 7.9 & 1.7 & 2.4 & 10.3 & 23 & 0 & 1.2 & 10.0 & 70 & 141 & 789 \\
\hline $\mathrm{Bw}_{4}$ & $1.0-1.5$ & 5.2 & 2.0 & 0.4 & 5.0 & 0.4 & 2.5 & 7.5 & 33 & 0 & 0.8 & 5.4 & 106 & 174 & 720 \\
\hline $\mathrm{Bw}_{5}$ & $-1.6+$ & 5.6 & 1.6 & 2.0 & 4.6 & 0.0 & 3.6 & 8.2 & 44 & 1 & 0.8 & 6.0 & 83 & 195 & 722 \\
\hline
\end{tabular}

$\mathrm{pH}$ in water (1:2.5); $\mathrm{Ca}$ and $\mathrm{Mg}, \mathrm{H}+\mathrm{Al}$ extracted in $1000 \mathrm{Mol} \mathrm{m}{ }^{-3} \mathrm{KCl}$; $\mathrm{Al}$ extracted in $1000 \mathrm{Mol} \mathrm{m}^{-3}$ calcium acetate at $\mathrm{pH}$ 7.0; P and $\mathrm{K}$ extracted with North Carolina solution; C extracted with potassium dichromate - Walkley - Black. (DONAGEMMA et al., 2011). 
Waste from oil well drilling and prospecting was deposited in the studied soil over 20 years ago. It is composed of fragmented rock mixed with well drilling fluid (removed during well drilling). In the area, there is also deposition of sediments from upstream soil erosion by surface runoff.

A geostatistical model was used to measure spatial variability of barium $(\mathrm{Ba})$ and lead $(\mathrm{Pb})$ in the area. To this end, a $15-\mathrm{m}$ soil sampling grid was created, with 76 sampling points. Each point was georeferenced at each grid vertex using a topographic global positioning system (GPS) with post-processing differential correction (DGPS Trimble Pro XT model). The UTM coordinate system was used (fuse 22 and horizontal datum SAD 69). To further improve the accuracy, a differential correction was used, with sub-meter accuracy (average location error equal to $0.6 \mathrm{~m}$ ). At each point, soil samples were collected from the following depth layers: $0.0-0.3,0.3-0.6,0.6-0.9$, and 0.9-1.2 m. Each sampling trench was dug using a backhoe loader, and soil samples were collected by hand.

\section{Chemical analyses}

All samples were analyzed for pseudo-total levels of $\mathrm{Ba}$ and $\mathrm{Pb}$ by EPA 3051 (USEPA, 1994). Thirty of the samples with the highest pseudo-total concentrations were selected for analysis by NBR 10004 (ABNT, 2004a). Leaching and solubilization tests were carried out following NBR 10005 (ABNT, 2004b) and NBR 10006 (ABNT, 2004c) standards, respectively.

For leaching assay, a 100-g sample was sieved through a $0.0095-\mathrm{m}$ mesh sieve and added with 11.4-mL extractant solution of glacial acetic acid in 2-L deionized water $(\mathrm{pH}=4.93)$. This solution was stirred at $30 \mathrm{rpm}$ and $25^{\circ} \mathrm{C}$ for $18 \mathrm{~h}$, using a flask of inert material (borosilicate glass). Then it was filtered through 0.6 - to $0.8-\mu \mathrm{m}$ fiberglass filter to obtain the leachate for analysis. Additionally, a 250-g sample was sieved through a $0.0095-\mathrm{m}$ mesh sieve and added with deionized water in a $1,500-\mathrm{mL}$ flask, then stirred at low speed for $5 \mathrm{~min}$. The flask was covered by a PVC film and left to rest for 7 days at $25^{\circ} \mathrm{C}$. After, the solution was filtered through a $0.45-\mu \mathrm{m}$ membrane, and solubilized extract was analyzed.

Concentrations of $\mathrm{Ba}$ and $\mathrm{Pb}$ in soil extracts were determined by plasma emission spectrometry (ICP-OES) (Perkin Elmer, OPTIMA 3000 model). The method detection limit (DL) was calculated as the blank mean plus three times the standard deviation of the blank of all analyses (10 replications). The $\mathrm{DLs}$ for $\mathrm{Ba}$ and $\mathrm{Pb}$ were 0.036 and $0.25 \mathrm{mg} \mathrm{kg}^{-1}$, respectively. The QLs (quantification limits) for $\mathrm{Ba}$ and $\mathrm{Pb}$ were 0.36 and $0.5 \mathrm{mg} \mathrm{kg}^{-1}$, respectively. The methods were validated by certified reference material: NIST SRM 2709a (San Joaquin Soil) with Ba content of $979 \pm 28 \mathrm{mg} \mathrm{kg}^{-1}$
(95\% of recovery) and $\mathrm{Pb}$ content of $17.3 \mathrm{mg} \mathrm{kg} \mathrm{kg}^{-1}$ ( $92 \%$ recovery). The results of certified reference materials were within the confidence limits stated by NIST.

\section{Barium and lead spatial variability}

Ordinary kriging geostatistical interpolation was used to create $\mathrm{Ba}$ and $\mathrm{Pb}$ concentration isoline maps. After spatial dependence was identified and measured, maps were produced with precision and without trends. Isovalue maps were then generated using the following procedures: 1) descriptive statistical analysis, 2) spatial dependence determination (variography), 3) semi-variogram modeling and validation, and 5) interpolation. All the steps were performed by GEOESTAT software (VIEIRA et al., 1983).

The models fitted to the semivariograms were validated by nugget effect $\left(\mathrm{C}_{0}\right)$, range $(\mathrm{a})$, sill $\left(\mathrm{C}_{0}+\mathrm{C}_{1}\right)$, spatial dependence index $\frac{C_{0}}{C_{0}+C_{1}}$, and $\mathrm{R}^{2}$ values, which are often used to evaluate interpolation performance.

\section{RESULTS AND DISCUSSION}

\section{Descriptive analysis of soil levels of barium and lead}

The overall sample mean for Ba level was $732.15 \mathrm{mg} \mathrm{kg}^{-1}$ (Table 2), the maximum was $10,557.00 \mathrm{mg} \mathrm{kg}^{-1}$ and the minimum was below $0.036 \mathrm{mg} \mathrm{kg}^{-1}$ (undetected). As standard values have not been established yet for Paraná State, we used the reference values in resolution $n^{\circ} 420$ of the Brazilian Council for the Environment - CONAMA (BRASIL, 2009). At all depth layers, Ba contents were higher than the limit in the most restrictive scenario (Agricultural/AP-Max), which is $300 \mathrm{mg} \mathrm{kg}^{-1}$. The Ba contents were about 30 times higher than the limit for agricultural areas. Barium concentrations were even higher than the limit for industrial areas, which is $750 \mathrm{mg} \mathrm{kg}^{-1}$. According to Magalhães et al. (2014b) and Freitas et al. (2015), Ba concentration in areas contaminated by oil well drilling residues is increased due to waste disposal near the wells. It is worth mentioning that $\mathrm{Ba}$ has no direct relationship with the genesis of local rocks or respective mineralization, as seen in local geochemical surveys (LICHT; BITTENCOURT, 2013). In the soils of northern Paraná State, natural levels of $\mathrm{Ba}$ fluctuate within a range between 38.5 to $63 \mathrm{mg} \mathrm{kg}^{-1}$ (PAVELHAO, 2015). In the coastal plain of the state, the levels are even lower $\left(<0.17 \mathrm{mg} \mathrm{kg}^{-1}\right)$ (BUSCHLE, 2013). That said, the abnormal levels found in this study may result from oil well drilling waste incorporation. 
N. M. B. AMARAL SOBRINHO et al.

Table 2. Mean, minimum, and maximum contents of barium and lead in soil samples.

\begin{tabular}{ccccc}
\hline & \multicolumn{5}{c}{ Depth (m) } \\
& $0-0.3$ & $0.3-0.6$ & $0.6-0.9$ & $0.9-1.2$ \\
\cline { 2 - 5 } & \multicolumn{5}{c}{ Metals } \\
\cline { 2 - 5 } & \multicolumn{5}{c}{ Barium $\left(\mathrm{mg} \mathrm{kg}^{-1}\right)$} \\
\hline Mean & 983.31 & 814.06 & 550.03 & 581.18 \\
Maximum & 8928.16 & 10557.00 & 6256.60 & 6716.21 \\
Minimum & 16.54 & 15.86 & $<0.036$ & $<0.036$ \\
\hline & \multicolumn{5}{c}{ Lead $\left(\mathrm{mg} \mathrm{kg}^{-1}\right)$} \\
\hline Mean & 38.61 & 24.60 & 12.36 & 14.75 \\
Maximum & 602.49 & 314.41 & 218.59 & 165.65 \\
Minimum & $<0.25$ & $<0.25$ & $<0.25$ & $<0.25$ \\
\hline
\end{tabular}

The overall sample mean for the $\mathrm{Pb}$ level was $22.58 \mathrm{mg} \mathrm{kg}^{-1}$, the maximum was $602.49 \mathrm{mg} \mathrm{kg}^{-1}$, and the minimum was below $0.25 \mathrm{mg} \mathrm{kg}^{-1}$ (undetected). The maximum values at the depth layers of $0.0-0.3,0.3-0.6,0.6-0.9$ and $0.9-1.2 \mathrm{~m}$ were $602.49,314.41,218.59$, and $165.65 \mathrm{mg} \mathrm{kg}^{-1}$, respectively, while the minimum value was below $0.25 \mathrm{mg} \mathrm{kg}^{-1}$ (undetected) at all four depth layers (Table 2). In one of the sampling points, the $\mathrm{Pb}$ contents were also higher than the limit in the most restrictive scenario (Agricultural/AP-Max), which is $180 \mathrm{mg} \mathrm{kg}^{-1}$. Moreover, in the three upper layers, the maximum values reached were higher than the reference values established by CONAMA (BRASIL, 2009). In the 0.0-0.3 $\mathrm{m}$ depth interval, the maximum content was about three times higher than the references. Therefore, the area is not only contaminated by $\mathrm{Ba}$ but also by $\mathrm{Pb}$ up to a depth of
$0.9 \mathrm{~m}$. When considering maximum allowable $\mathrm{Pb}$ contents for farmland of other countries, the values found in the study area are also above the standards of the European Union (50-300 mg kg${ }^{-1}$ ) and the United States (150 $\mathrm{mg} \mathrm{kg}^{-1}$ ) (MCGRATH et al., 1994).

\section{Spatial variability in depth of barium and lead}

For $\mathrm{Ba}$, the Gaussian model showed determination coefficient values $\left(\mathrm{R}^{2}\right)$ equal to or above 0.80 , at the four depth layers (Table 3 ). However, for $\mathrm{Pb}$, the 0.0-0.3 and 0.6-0.9 $\mathrm{m}$ depth layers showed a more erratic behavior when using the Gaussian model, with $\mathrm{R}^{2}$ values much lower than those observed for Ba at these depths. At the 0.3-0.6 $\mathrm{m}$ and 0.9-1.2 $\mathrm{m}$ depth layers, the spherical model presented better fit, with higher $\mathrm{R}^{2}$ values.

Table 3. Parameters of the models adjusted to the experimental semivariograms

\begin{tabular}{|c|c|c|c|c|c|c|c|}
\hline Attribute & Model & $\mathrm{C}_{0}$ & $\mathrm{C}_{1}$ & Level & $\mathrm{Co} / \mathrm{Co}+\mathrm{C} 1$ & Range (m) & $\mathrm{R}^{2}$ \\
\hline $\mathrm{Ba} \mathrm{0-0.3 \textrm {m }}$ & Gaussian & 0.19 & 0.34 & 0.53 & 0.36 & 63.8 & 0.80 \\
\hline Ва $0.3-0.6 \mathrm{~m}$ & Gaussian & 0.10 & 0.43 & 0.53 & 0.19 & 53.2 & 0.85 \\
\hline Ва 0.6- $0.9 \mathrm{~m}$ & Gaussian & 0.10 & 0.39 & 0.49 & 0.20 & 59.5 & 0.84 \\
\hline Ва $0.9-1.2 \mathrm{~m}$ & Gaussian & 0.10 & 0.40 & 0.50 & 0.20 & 50.0 & 0.85 \\
\hline $\mathrm{Pb} \mathrm{0-0.3 \textrm {m }}$ & Gaussian & 0.35 & 0.24 & 0.59 & 0.59 & 59.7 & 0.54 \\
\hline $\mathrm{Pb} 0.3-0.6 \mathrm{~m}$ & Spherical & 0.23 & 0.22 & 0.45 & 0.51 & 57.3 & 0.56 \\
\hline $\mathrm{Pb} 0.9-1.2 \mathrm{~m}$ & Spherical & 0.09 & 0.23 & 0.32 & 0.28 & 59.4 & 0.84 \\
\hline
\end{tabular}

Comparing each parameter for $\mathrm{Ba}$ in the different depth layers, a total agreement was observed, that is, according to depth and metal type the parameters had a good fit. This is because Co (nugget effect) varied from 0.10 to 0.19 (Table 3 ), $\mathrm{R}^{2}$ was greater than 0.8 , and range above $50 \mathrm{~m}$. Amaral Sobrinho et al. (2018) found similar Gaussian model fit results to $\mathrm{Ba}$ distribution data, which were also collected in waste disposal areas for oil well drilling and prospecting. Accordingly, a 15 x 15-m grid was suitable for the range values found. However, for $\mathrm{Pb}$, the nugget effect $(\mathrm{Co})$ and $\mathrm{R}^{2}$ values with the best fit were found only at the 0.9-1.2 $\mathrm{m}$ depth layer; yet, the range values were suitable with a good autocorrelation for all depth layers. These values of range highlight that the $\mathrm{Pb}$ had a spatial variability pattern other than random (GUEDES et al., 2012). The mean $\mathrm{R}^{2}$ values at the depths $0-0.3,0.3-0.6$, and 0.6-0.9 $\mathrm{m}$ do not necessarily denote that data interpolation was lower at these layers. This is because $\mathrm{R}^{2}$ refers only to model fit for all semivariance points. What matters, however, for geostatistical interpolation is the model fitting to the semivariance points within the range limit.

Spatial dependence of $\mathrm{Ba}$ and $\mathrm{Pb}$ contents was identified by means of geostatistical treatment; hence, geostatistical interpolators could be used to generate spatial variability maps for the four soil layers $(0.0-0.3,0.3-0.6,0.6-0.9$, and $0.9-1.2 \mathrm{~m})$ (Figure 1). The green areas correspond to classes 1 
and 2 (BRASIL, 2009), which have concentrations up to the limit value for prevention, for $\mathrm{Ba}(0$ and $150 \mathrm{mg} \mathrm{kg}^{-1}$ ) and for $\mathrm{Pb}$ (between 0 and $72 \mathrm{mg} \mathrm{kg}^{-1}$ ). The blue area comprises class 3, in which concentrations were above the prevention limits and below investigation limits, for $\mathrm{Ba}$ (between 150-300 $\left.\mathrm{mg} \mathrm{kg}{ }^{-1}\right)$ and for $\mathrm{Pb}\left(73-180 \mathrm{mg} \mathrm{kg}^{-1}\right)$. Shades from pink to black were classified as class 4 . In the case of $\mathrm{Ba}$, other hues were added due to a large range of values. Also for $\mathrm{Ba}$, the sum of the percentages of
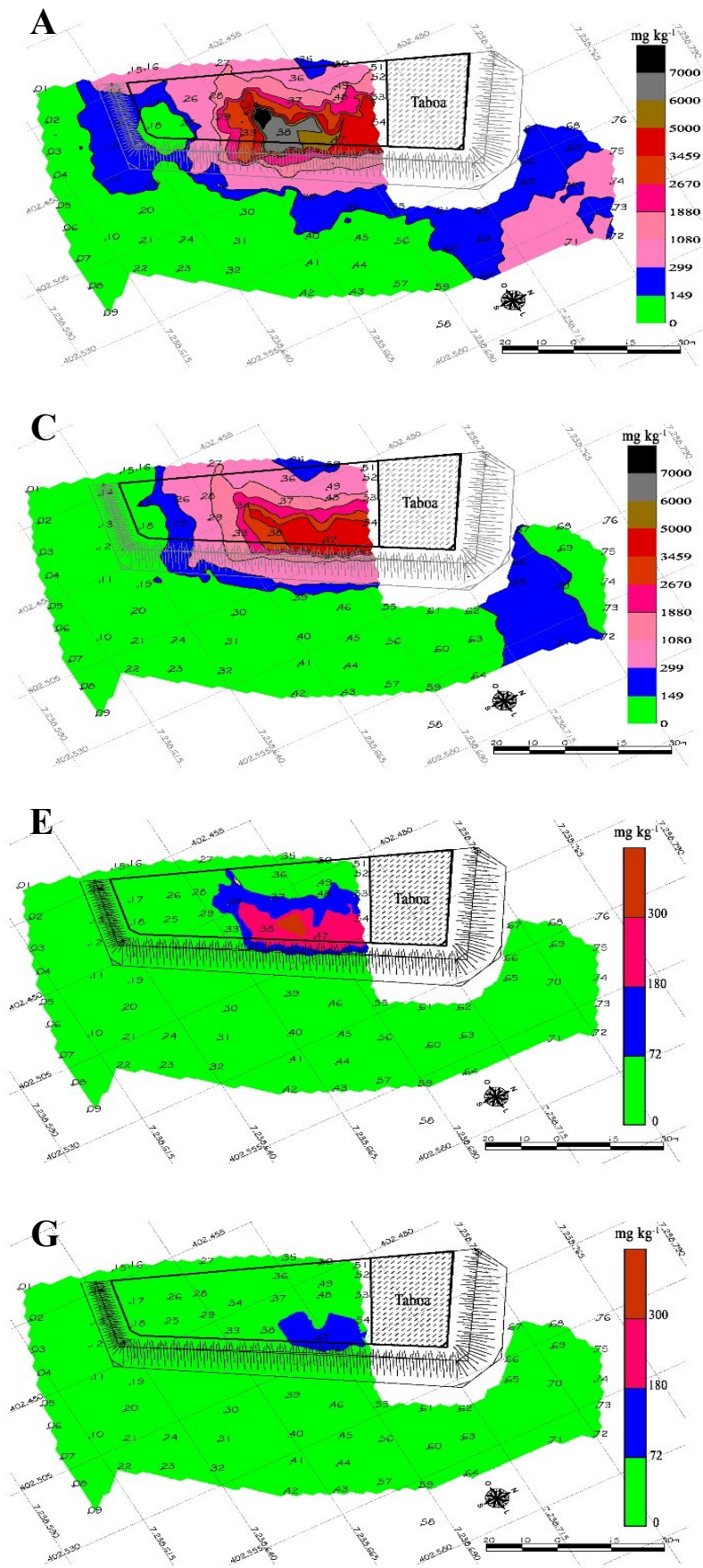

areas classified as class 3 and class 4 reaches more than $50 \%$ of the total at all depth layers. For $\mathrm{Pb}$, classes 1 and 2 represent over $90 \%$ of the area, and most of the contamination is within the first $0.6 \mathrm{~m}$ depth and around the waste disposal dike. This indicates that more than $50 \%$ of the area has $\mathrm{Ba}$ concentrations that disturb soil main functions and pose direct or indirect risks to human health (BRASIL, 2009).

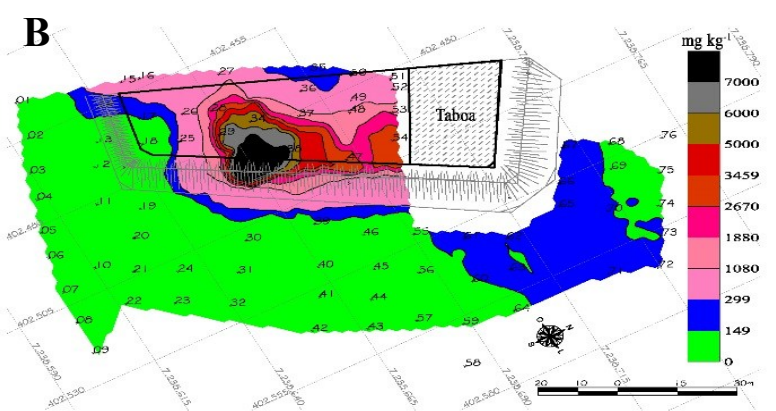

D
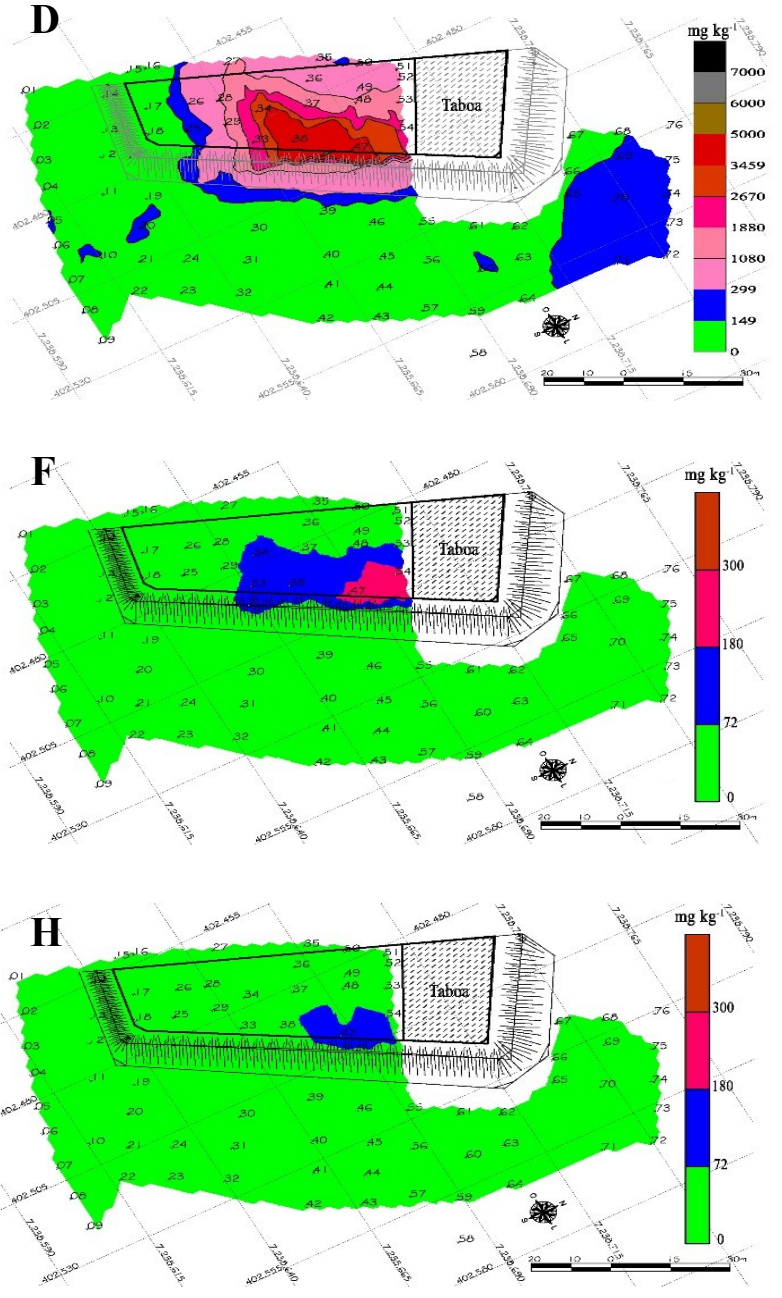

Figure 1. Spatial variability of barium (A, B, C, and D) and lead (E, F, G, and H) at the depth layers of 0-0.3, 0.3-0.6, $0.6-0.9$ and $0.9-1.2 \mathrm{~m}$, respectively. 


\section{Leaching and solubilization tests}

Thirty samples with higher pseudo-total concentrations of $\mathrm{Ba}$ and $\mathrm{Pb}$ were selected. All these samples had concentrations of both elements below the limit for leaching test according to NBR-10005
(ABNT, 2004b), $70 \mathrm{mg} \mathrm{L}^{-1}$ for Ba and $1.00 \mathrm{mg} \mathrm{L}^{-1}$ for $\mathrm{Pb}$. Likewise, the contents of all samples were below the limit for solubilization test according to NBR-10006 (ABNT, 2004c), $0.7 \mathrm{mg} \mathrm{L}^{-1}$ for Ba and $0.01 \mathrm{mg} \mathrm{L}^{-1}$ for $\mathrm{Pb}$ (Table 4).

Table 4. Leached and solubilized contents of barium and lead in soil samples from well drilling waste disposal area.

\begin{tabular}{|c|c|c|c|c|c|c|c|c|c|}
\hline \multirow{3}{*}{ Sample } & \multirow{3}{*}{$\begin{array}{l}\text { Depth } \\
\text { (m) }\end{array}$} & \multirow{2}{*}{\multicolumn{2}{|c|}{ Georeference }} & \multicolumn{3}{|c|}{ Barium } & \multicolumn{3}{|c|}{ Lead } \\
\hline & & & & \multirow{2}{*}{$\frac{\text { Total }}{\mathrm{mg} \mathrm{kg}^{-1}}$} & \multirow{2}{*}{$\frac{\text { Leach }}{\mathrm{mg} \mathrm{L}^{-1}}$} & \multirow{2}{*}{$\frac{\text { Solub }}{\mathrm{mg} \mathrm{kg}^{-1}}$} & \multirow{2}{*}{$\frac{\text { Total }}{\mathrm{mg} \mathrm{kg}^{-1}}$} & \multirow{2}{*}{$\frac{\text { Leach }}{\mathrm{mg} \mathrm{L}^{-1}}$} & \multirow{2}{*}{$\frac{\text { Solub }}{\mathrm{mg} \mathrm{kg}^{-1}}$} \\
\hline & & $\mathrm{L}$ & $\mathrm{N}$ & & & & & & \\
\hline 15 & $0.3-0.6$ & 402451 & 7238648 & 859.3 & 7.60 & 0.162 & nd & 0.011 & nd \\
\hline 16 & $0.3-0.6$ & 402452 & 7238653 & 938.9 & 5.54 & 0.118 & 1.6 & nd & nd \\
\hline 27 & $0.9-1.2$ & 402461 & 7238671 & 872.6 & 3.91 & 0.313 & 1.9 & nd & nd \\
\hline 28 & $0-0.3$ & 402470 & 7238664 & 5484.6 & 15.82 & 0.012 & 199.1 & 0.133 & nd \\
\hline 28 & $0.9-1.2$ & 402470 & 7238664 & 1477.0 & 1.95 & 0.102 & 4.1 & nd & nd \\
\hline 29 & $0.3-0.6$ & 402477 & 7238662 & 8585.0 & 10.79 & 0.666 & 210.1 & 0.096 & nd \\
\hline 33 & $0-0.3$ & 402485 & 7238666 & 8928.2 & 9.73 & 0.650 & 75.6 & 0.030 & nd \\
\hline 33 & $0.9-1.2$ & 402485 & 7238666 & 3396.6 & 2.15 & 0.144 & 20.6 & 0.004 & nd \\
\hline 34 & $0-0.3$ & 402477 & 7238671 & 7108.9 & 5.77 & 0.399 & 456.9 & 0.260 & nd \\
\hline 34 & $0.9-1.2$ & 402477 & 7238671 & 6716.2 & 3.10 & 0.216 & 72.3 & 0.055 & nd \\
\hline 37 & $0-0.3$ & 402486 & 7238682 & 7711.9 & 6.64 & 1.137 & 602.5 & 0.660 & nd \\
\hline 37 & $0.9-1.2$ & 402486 & 7238682 & 3713.5 & 4.54 & 0.178 & 83.9 & 0.137 & nd \\
\hline 38 & $0-0.3$ & 402490 & 7238675 & 5122.9 & 5.23 & 0.348 & 142.5 & 0.061 & nd \\
\hline 38 & $0.3-0.6$ & 402490 & 7238675 & 10557.0 & 5.18 & 0.687 & 159.5 & 0.103 & nd \\
\hline 38 & $0.9-1.2$ & 402490 & 7238675 & 4091.5 & 2.63 & 0.166 & 78.0 & 0.013 & nd \\
\hline 47 & $0-0.3$ & 402499 & 7238687 & 5459.6 & 3.81 & 0.580 & 314.9 & 0.226 & nd \\
\hline 47 & $0.9-1.2$ & 402499 & 7238687 & 6469.1 & 4.10 & 0.223 & 165.6 & 0.059 & nd \\
\hline 48 & $0-0.3$ & 402487 & 7238694 & 6894.3 & 3.97 & 0.586 & 437.2 & 0.168 & nd \\
\hline 48 & $0.3-0.6$ & 402487 & 7238694 & 1806.8 & 2.26 & 0.234 & 233.5 & 0.340 & nd \\
\hline 48 & $0.6-0.9$ & 402487 & 7238694 & 3107.7 & 0.88 & 0.155 & 218.6 & 0.190 & nd \\
\hline 48 & $0.9-1.2$ & 402487 & 7238694 & 2484.8 & 3.15 & 0.112 & 149.3 & 0.137 & nd \\
\hline 52 & $0-0.3$ & 402486 & 7238707 & 5100.4 & 10.52 & 0.164 & 98.4 & 0.027 & nd \\
\hline 52 & $0-0.3$ & 402492 & 7238703 & 3961.1 & 4.48 & 0.244 & 128.9 & 0.036 & nd \\
\hline 53 & $0.9-1.2$ & 402492 & 7238703 & 4296.8 & 1.45 & 0.283 & 88.7 & 0.030 & nd \\
\hline 54 & $0-0.3$ & 402499 & 7238700 & 3726.7 & 1.70 & 0.101 & 185.0 & 0.019 & nd \\
\hline 54 & $0.6-0.9$ & 402499 & 7238700 & 5591.1 & 2.82 & 0.200 & 62.3 & 0.064 & nd \\
\hline 54 & $0.9-1.2$ & 402499 & 7238700 & 1348.0 & 1.28 & 0.032 & 156.9 & 0.054 & nd \\
\hline 70 & $0-0.3$ & 402544 & 7238736 & 2076.1 & 3.12 & 0.100 & 8.2 & 0.021 & nd \\
\hline 74 & $0-0.3$ & 402549 & 7238749 & 1507.4 & 4.71 & 0.214 & 6.7 & nd & nd \\
\hline 75 & $0-0.3$ & 402540 & 7238754 & 875.8 & 2.74 & 0.145 & 16.6 & nd & nd \\
\hline
\end{tabular}

Leach - leached; Solub - solubilized; nd - not detected.

The low solubility of barite-derived Ba has already been reported in studies on soils with varying organic matter, iron, calcium, and sulfur contents (CAPPUYNS, 2017) and soil from A horizon of a Red-Yellow Latosol (MAGALHÃES. et al., 2011; LIMA et al., 2012; MAGALHÃES et al., 2014a). This low solubility is due to the high $\mathrm{pH}$ and redox potential (Eh), resulting in its slow release to the soil. Barium tends to remain in poorly soluble forms (NOGUEIROL; ALLEONI, 2013) with sulfate ion, which makes it more associated with sediment contamination than with water (DAVIDSON et al., 2005). Barium soluble fraction only increases under extreme reduction conditions $(\mathrm{Eh}<-250 \mathrm{mV})$, hence increasing its mobility and bioavailability (LIMA et al., 2012; MAGALHÃES et al., 2014a; MAGALHÃES et al., 2014b; SAMPAIO JUNIOR et al., 2015).

Pseudo-total concentrations of $\mathrm{Ba}$ and $\mathrm{Pb}$ to reach the maximum limit for leaching and solubilization assays were estimated using data from Table 4. This way, regression curves could be plotted (Figure 2), finding $\mathrm{R}^{2}$ values equal to $0.85,0.95$, and 0.89 for $\mathrm{Ba}$ solute, $\mathrm{Ba}$ leachate, and $\mathrm{Pb}$ leachate, respectively. 

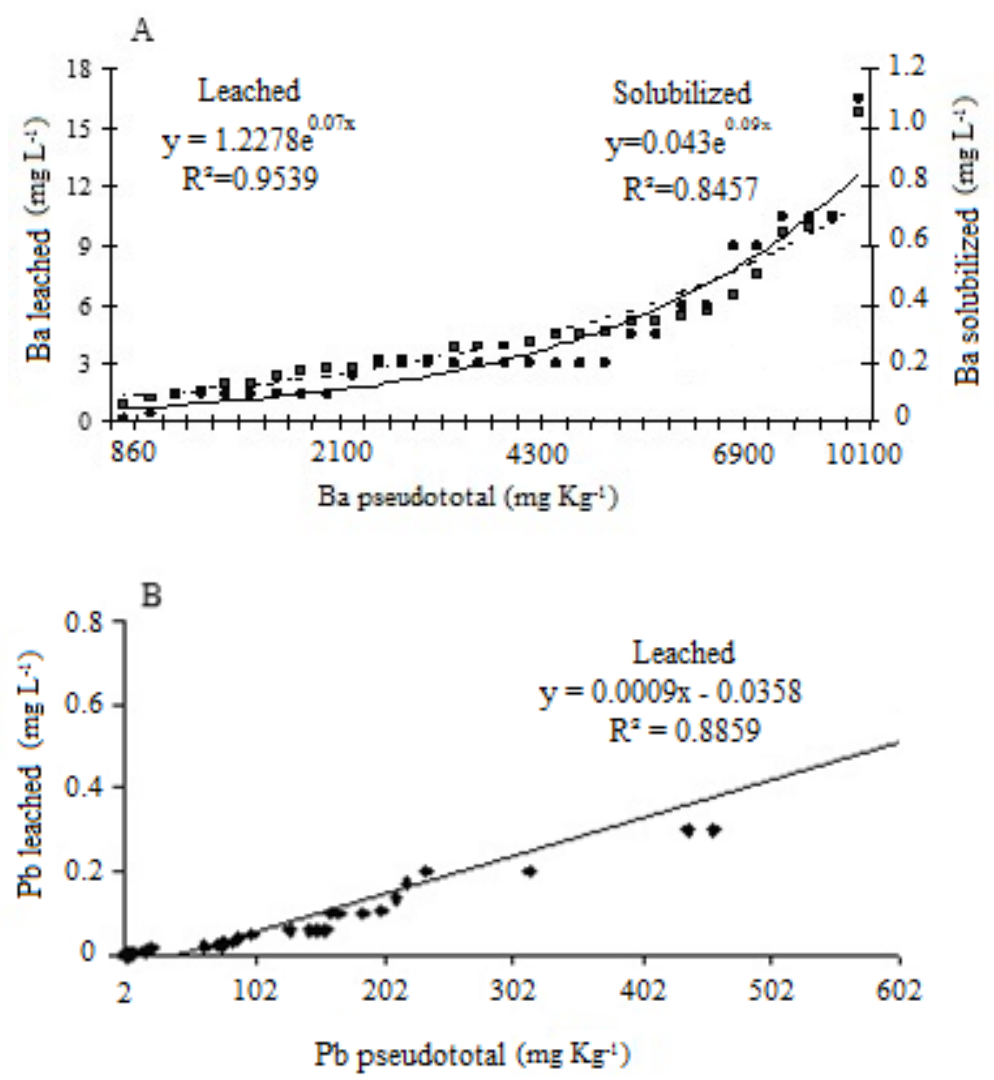

Figure 2. Regression analysis for contents of barium (leached and solubilized) (A) and lead (leached) (B) as a function of total contents in the soil.

The regression curve equation shows that $\mathrm{Ba}$ pseudo-total concentrations above $61,000 \mathrm{mg} \mathrm{kg}^{-1}$ are able to reach the upper limit for leaching $\left(70 \mathrm{mg} \mathrm{L}^{-1}\right)$. This is 6 times the value of the most concentrated sample $\left(10,557.00 \mathrm{mg} \mathrm{kg}^{-1}\right)$, for both leaching and solubilization analysis. On the other hand, for $\mathrm{Pb}$, the concentrations should be above $1,071.33 \mathrm{mg} \mathrm{kg}^{-1}$ to reach the limit for leaching $\left(1 \mathrm{mg} \mathrm{L}^{-1}\right)$. This is about 1.8 times the value of the most concentrated sample (602.50 mg kg${ }^{-1}$ ), according to the maximum limits defined in NBR-10004 (ABNT, 2004a).

\section{CONCLUSIONS}

The study area is contaminated by barium and lead according to the current legislation.

In all samples, lead and barium concentrations were below the limit for leaching analysis defined in NBR-10005 standard (ABNT, 2004b) and also below the limit for solubilization analysis (ABNT, 2004c).

Although barium and lead showed high pseudo-total concentrations in soils where oil well drilling wastes were disposed, leading to investigation values higher than the most restrictive scenario (Agricultural/AP-Max), defined by CONAMA's resolution $\mathrm{n}^{\circ} 420$ (BRASIL, 2009), both metals showed low solubility. Thus, under proper removal and disposal conditions, the soil has a low risk of contaminating subsurface water through leaching; however, water bodies can be contaminated by soil runoff.

\section{ACKNOWLEDGMENTS}

The authors would like to thank Fapur/ UFRRJ and Petrobras for their support.

\section{REFERENCES}

ASSOCIAC̄̃̃O BRASILEIRA DE NORMAS TÉCNICAS - ABNT. NBR 10004: Resíduos sólidos - Classificação. Rio de Janeiro, 2004a. 71 p.

ASSOCIAÇÃO BRASILEIRA DE NORMAS TÉCNICAS - ABNT. NBR 10005: Procedimento para obtenção de extrato lixiviado de resíduos sólidos. Rio de Janeiro, 2004b. 16 p.

ASSOCIAÇÃO BRASILEIRA DE NORMAS TÉCNICAS - ABNT. NBR 10006: Procedimento para obtenção de extrato solubilizado de resíduos sólidos. Rio de Janeiro, 2004c. 3 p.

ANDRADE, A. F. M. et al. EDTA-induced 
phytoextraction of lead and barium by brachiaria (B. decumbens cv. Basilisk) in soil contaminated by oil exploration drilling waste. Acta Scientiarum. Agronomy, v. 36, n. 4, p. 495-500, 2014.

AMARAL SOBRINHO, N. M. B. et al. Spatial variability and solubility of barium in a petroleum well-drilling waste disposal area. Environmental Monitoring and Assessment, v. 190, n. 4, p. 228238, 2018.

BAUDER, T. A. et al. Soil properties affecting wheat yields following drilling-fluid application. Journal of Environmental Quality, v. 34, n. 5, p. 1687-1696, 2005.

BRASIL. Conselho Nacional do Meio ambiente. Resolução $n^{\circ} 420$ de 28 de dezembro de 2009. Disponível em: <http://www2.mma.gov.br/port/ conama/legiabre.cfm?codlegi $=620>$. Acesso em: 29 de nov. 2018.

BUSINELLI, D. et al. Long-term distribution, mobility and plant availability of compost-derived heavy metals in a landfill covering soil. Science of the Total Environment, v. 407, n. 4, p. 1426-1435, 2009.

BAKKE, T., KLUNGSØYR, J., SANNI, S. Environmental impacts of produced water and drilling waste discharges from the Norwegian offshore petroleum industry. Marine Environmental Research, v. 92, n. 1, p. 154-169, 2013.

BUSCHLE, B. N. Valores de referência de qualidade para elementos-traço em solos da planície litorânea do estado do Paraná. 2013. $41 \mathrm{f}$. Dissertação (Mestrado em Ciência do Solo: Área de Concentração em Solo e Ambiente) - Universidade Federal do Paraná, Curitiba, 2013.

CAPPUYNS, V. Barium (Ba) leaching from soils and certified reference materials. Applied Geochemistry, v. 88, n. 1, p. 68-84, 2017.

CARVALHO, J. R. P.; SILVEIRA, P. M.; VIEIRA, S. R. Geoestatistica na determinação da variabilidade espacial de características químicas do solo sob diferentes preparos. Pesquisa Agropecuária Brasileira, v. 48, n. 8, p. 1151-1159, 2002.

DAVIDSON, C. M. et al. The long-term environmental behavior of strontium and barium released from former mine workings in the granites of the Sunart region of Scotland, UK. Chemosphere, v. 58, n. 6, p. 793-798. 2005. de análise de solos. 2.ed. Rio de Janeiro, RJ: Embrapa Solos, 2011. 230 p. (Documentos, 132).

ESMAEILI, A. et al. A geochemical survey of heavy metals in agricultural and background soils of the Isfahan industrial zone, Iran. Catena, v. 121, n. 1, p. 88-98, 2014.

FREITAS, F. C. et al. pH, sódio, potássio, cálcio, magnésio e alumínio em solos contaminados com fluido de perfuração de poços de petróleo após ensaios de lixiviação. Ciência Rural, v. 45, n. 8, p. 1418-1423, 2015.

GHERASIM, C.V.; MIKULÁŠEK, P. Influence of operating variables on the removal of heavy metal ions from aqueous solutions by nanofiltration. Desalination, v. 343, n. 16, p. 67-74, 2014.

GUEDES, J. N. et al. Concentration and Spatial Distribution of Lead in Soil Used for Ammunition Destruction. Bulletin of Environmental Contamination and Toxicology, v. 89, n. 1, p. 775 781,2012

LICHT, O. A. B.; BITTENCOURT, A. V. Paisagens geoquímicas - naturais e antrópicas no estado do Paraná. Revista Técnico-Científica do CREA-PR, v. 1, n. 1, p. 1-27, 2014

LIMA, E. S. A. et al. Absorção de Bário por Plantas de Arroz (Oryza Sativa L.) e Mobilidade em Solo Tratado com Baritina sob Diferentes Condições de Potencial Redox. Química Nova, v. 35, n. 9, p. 1746 -1751, 2012.

MAGALHÃES, M. O. L. et al. Mobilidade de bário em solo tratado com sulfato de bário sob condição de oxidação e redução. Química Nova, v. 34, n. 9, p. 1544-1549, 2011.

MAGALHÃES, M. O. L. et al. Reducing conditions on barium absorption in rice plants cultured in BaSO4-enriched soil. Acta Scientiarum. Agronomy, v. 36, n. 1, p. 119-127, 2014a.

MAGALHÃES, M. O. L. et al. The Effects of Oil Well Drill Cuttings on Soil and Rice Plant Development (Oryza sativa) Under Two Redox Conditions. Bulletin of Environmental Contamination and Toxicology, v. 92, n. 3, p. 311$316,2014 b$.

MCGRATH, S. P. et al. Land application of sewage sludge: scientific perspectives of heavy metal loading limits in Europe and the United States. Environmental Reviews, v. 2, n. 1, p. 108-118, 1994.

NOGUEIROL, R. C.; ALLEONI, L. R. F. Sequential

DONAGEMMA, G. K. et al. Manual de métodos 
extraction and speciation of $\mathrm{Ba}, \mathrm{Cu}, \mathrm{Ni}, \mathrm{Pb}$ and $\mathrm{Zn}$ in soil contaminated with automotive industry waste. Chemical Speciation \& Bioavailability, v. 25, n. 1, p. 34-42, 2013.

ONG, S. A. et al. Comparative study on kinetic adsorption of $\mathrm{Cu}$ (II), $\mathrm{Cd}$ (II) and $\mathrm{Ni}$ (II) ions from aqueous solutions using activated sludge and dried sludge. Applied Water Science, v. 3, n. 1, p. 321325. 2013.

PAVELHAO, T. R. Valores orientadores de qualidade para metais pesados em solos cultivados no município de Bandeirantes - PR. 2015. 156 f. Tese (Doutorado em Geografia: Área de Concentração em Análise Ambiental) - Universidade estadual de Maringá, Maringá, 2015.

SAMPAIO JUNIOR, J. et al. Barium and sodium in sunflower plants cultivated in soil treated with wastes of drilling of oil well. Revista Brasileira de Engenharia Agrícola e Ambiental, v. 19, n. 11, p. 1100-1106, 2015.

SANTOS, H. G. et al. Sistema brasileiro de classificação de solos. 3ed. Brasília, DF: Empresa Brasileira de Pesquisa Agropecuária, 2013. 353 p.

SANTOS, M. B. Perfuração de poços de petróleo: fluidos de perfuração. Revista de divulgação do Projeto Universidade Petrobras e IF Fluminense, v. 2, n. 1, p. 121-127, 2012.

\section{UNITED STATES ENVIRONMENTAL}

PROTECTION AGENCY - USEPA. Method 3051: Microwave assisted acid digestion of sediments, sludges, soils, and oils. Washington, 1994. 14 p.

VIEIRA, S. R. et al. Geoestatistical theory and application to variability of some agronomical properties. Hilgardia, v. 51, n. 3, p. 1-75, 1983. 